\title{
Plasma cell leukemia of IgG secreting type: A rare case
}

\author{
Parth Anil Desai, Sagar Dholariya, Sanjeev Gupta, Tejinder Singh
}

\section{To the Editor,}

Plasma cell leukemia is very rare comprising $2 \%$ plasma cell dyscrasias [1]. We report a case of a 49-yearold male with complaints of chest pain, breathlessness, and acute attacks of gastroenteritis. On examination, there was marked pallor and hepatosplenomegaly. X-ray and computed tomography (CT) scan revealed multiple paratracheal lymph node enlargements. However, there was no diffuse osteopenia or multiple osteolytic lesions. Laboratory analysis revealed high serum calcium $11.5 \mathrm{mg} / \mathrm{dL}$, low hemoglobin $5 \mathrm{~g} / \mathrm{dL}$, normal WBC count, thrombocytopenia $22000 / \mathrm{mm}^{3}$ and elevated erythrocyte sedimentation rate (ESR). Peripheral smear showed many atypical cells (41\%) with blastoid morphology, giving a blood picture of acute leukemia. However, on closer inspection many of them appeared plasmacytoid. There was marked rouleaux formation of red cells in the background. Bone marrow aspirate and biopsy also revealed near total replacement by such atypical cells with plasmacytoid morphology. Serum electrophoresis revealed a prominent M spike and immunofixation revealed IgG heavy chain and kappa light chain immunostaining ruling out the possibility of Waldenström's macroglobulinemia. Plasma cell

Parth Desai ${ }^{1}$, Sagar Dholariya ${ }^{2}$, Sanjeev Gupta ${ }^{3}$, Tejinder Singh $^{4}$

Affiliations: ${ }^{1} \mathrm{MBBS}$, Resident Department of Pathology, MAMC, Maulana Azad Medical College, New Delhi; ${ }^{2}$ MBBS, Resident Department of Biochemistry, MAMC, Maulana Azad Medical College, New Delhi; ${ }^{3}$ DM Hematopathology, Professor AlIMS, Maulana Azad Medical College, New Delhi; ${ }^{4} \mathrm{MD}$ Pathology, Director Professor, MAMC, Maulana Azad Medical College, New Delhi.

Corresponding Author: Parth Anil Desai, MBBS, Resident, Department of Pathology, MAMC, Maulana Azad Medical College, New Delhi; Email: parth1410@gmail.com

Received: 07 May 2013

Accepted: 27 June 2013

Published: 01 December 2013

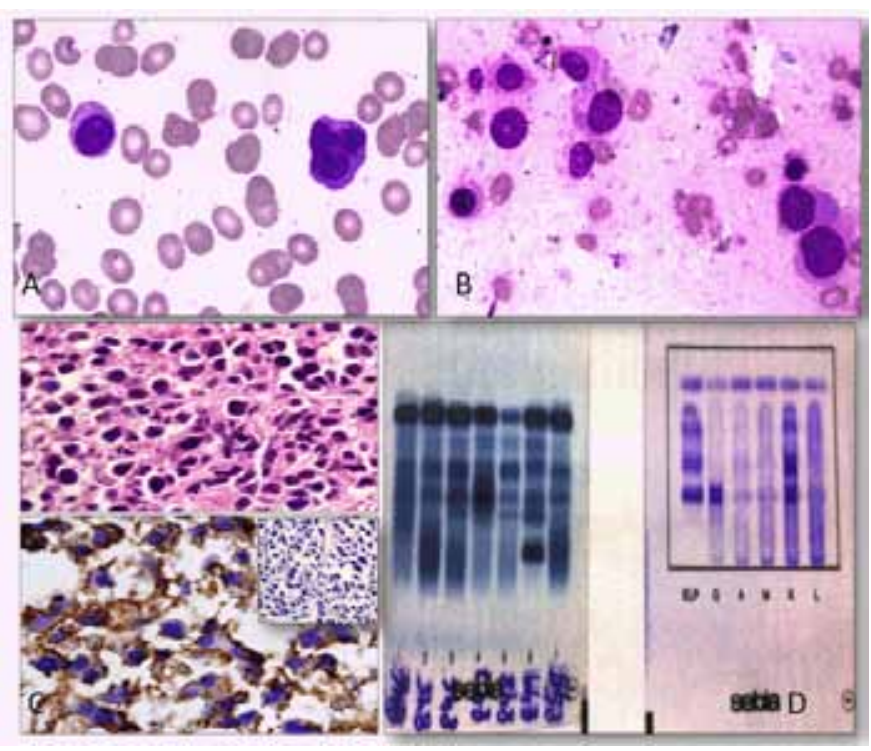

Figure 1: (A) Peripheral Smear (Giemsa): Blastoid cells with plasmacytoid cells and background rouleaux formation, (B) Bone marrow aspirate smear: Plasmacytoid cells with prominent nucleoli, (C) Bone marrow biopsy: Replacement by atypical plasmacytoid cells. Kappa positive and lambda (inset) negative immunostaining, (D) Serum electrophoresis (left) showing M spike and immunofixation (right) showing $\mathrm{G}$ heavy chain and kappa light chain.

leukemias are predominantly $\operatorname{IgD}$ and $\operatorname{IgE}$ secreting type [2-4]. This case is rare in that it is IgG secreting type. Plasma cell leukemias are very aggressive and with higher incidence of organomegaly, lymphadenopathy, thrombocytopenia, hypercalcemia, renal impairment and surprisingly lesser occurrence of lytic bony lesions as in our case $[1,2,4]$.

$* * * * * * * * *$

Desai PA, Dholariya S, Gupta S, Singh T. Plasma cell leukemia of IgG secreting type: A rare case. International Journal of Case Reports and Images 2013;4(12):748749 . 


\section{Copyright}

doi:10.5348/ijcri-2013-12-427-LE-21

$* * * * * * * * *$

\section{Author Contributions}

Parth Anil Desai - Substantial contributions to conception and design, Acquisition of data, Drafting the article, Revising it critically for important intellectual content, Final approval of the version to be published

Sagar Dholariya - Substantial contributions to conception and design, Acquisition of data, Drafting the article, Revising it critically for important intellectual content, Final approval of the version to be published

Sanjeev Gupta - Substantial contributions to conception and design, Acquisition of data, Drafting the article, Revising it critically for important intellectual content, Final approval of the version to be published

Tejinder Singh - Substantial contributions to conception and design, Acquisition of data, Drafting the article, Revising it critically for important intellectual content, Final approval of the version to be published.

\section{Guarantor}

The corresponding author is the guarantor of submission.

\section{Conflict of Interest}

Authors declare no conflict of interest.
(C) Parth Anil Desai et al. 2013; This article is distributed under the terms of Creative Commons attribution 3.0 License which permits unrestricted use, distribution and reproduction in any means provided the original authors and original publisher are properly credited. (Please see www.ijcasereportsandimages.com/copyright-policy.php for more information.)

\section{REFERENCES}

1. García-Sanz R, Orfão A, González M, et al. Primary plasma cell leukaemia: Clinical, immunophenotypic, DNA ploidy, and cytogenetic characteristics. Blood 1999 Feb 1;93(3):1032-7.

2. Kyle RA, Maldonado JE, Bayrd ED. Plasma cell leukaemia. Report on 17 cases. Arch Intern Med 1974 May;133(5):813-8.

3. Pruzanski W, Platts ME, Ogryzlo MA. Leukemic form of immunocytic dyscrasia (plasma cell leukaemia). A study of ten cases and a review of the literature. Am J Med 1969 Jul;47(1):60-74.

4. Dimopoulos MA, Palumbo A, Delasalle KB, Alexanian R. Primary plasma cell leukaemia. Br J Haematol 1994 Dec;88(4):754-9.
Access full text article on other devices

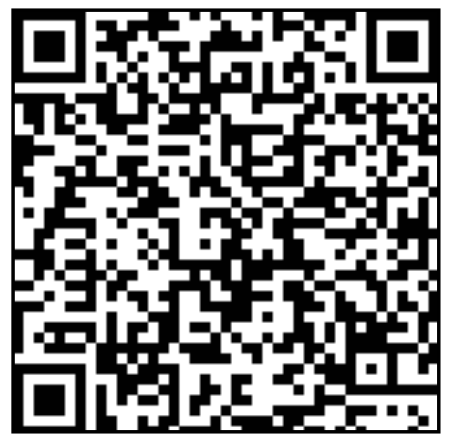

Access PDF of article on other devices

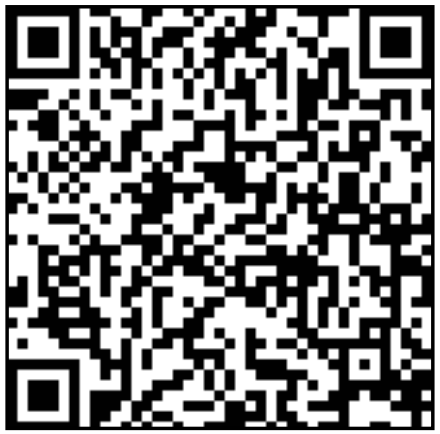

